\title{
THE ASSOCIATION OF BODY MASS INDEX AND MENSTRUAL PATTERN WITH THE INCIDENCE OF ANEMIA IN FEMALE ADOLESCENTS IN JAMBI, INDONESIA
}

\author{
Monika Mayang Sari, Adelina Fitri, Willia Novita Eka Rini \\ Study Program of Public Health Science, Universitas Jambi, Jambi
}

\begin{abstract}
Background: Anemia is a condition in which the number of red blood cells or the level of hemoglobin in red blood cells is below normal. The threshold of anemia for adolescents is $12 \mathrm{mg} / \mathrm{dl}$. In Jambi, the incidence of anemia in adolescents aged 15-18 years is fluctuative. There were 259 cases in 2015, 257 cases in 2016, and 1,169 cases in 2017. Many factors cause anemia in adolescents. This study aimed to determine the association of body mass index and menstrual pattern with the incidence of anemia among female adolescents in Jambi.

Subjects and Method: This was a case control study conducted at high school, Jambi, from December 2018 to June 2019. A sample of 290 female adolescents was selected at random, consisting of 65 case and 65 control. The dependent variable was anemia. The independent variables were body mass index and menstrual pattern. The data for anemia were collected from medical record documented in Payo Selincah Community Health Center. The data for independent variables were collected by questionnaire. The data were analyzed by odds ratio and chi-square.

Results: The incidence of anemia increased with underweight category of BMI (OR= $2.12 ; 95 \% \mathrm{CI}=0.52$ to $8.65 ; \mathrm{p}=0.338)$ and menstrual pattern $(\mathrm{OR}=4.67 ; 95 \% \mathrm{CI}=1.25$ to $17.48 ; \mathrm{p}=0.025$ ) in female adolescents.

Conclusion: The incidence of anemia increases with underweight category of BMI and menstrual pattern in female adolescents.

Keywords: anemia, body mass index, menstrual pattern, female adolescent

Correspondence:

Adelina Fitri. Study Program of Public Health Science, Universitas Jambi, Jambi. Jl Jambi - Muara Bulian 15, Mendalo Darat, Jambi, Indonesia. Email: adelinafitri@unja.ac.id. Mobile: +62 81272030308 .
\end{abstract}

